\title{
Isolation and Physiological Characterization of a Novel Algicidal Virus Infecting the Marine Diatom Skeletonema costatum
}

\author{
JinJoo Kim ${ }^{1}$, Chang-Hoon Kim ${ }^{2}$, Seok-Hyun Youn ${ }^{1}$ and Tae-Jin Choi ${ }^{3 *}$ \\ ${ }^{1}$ Fishery and Ocean Information Division, National Fisheries Research \& Development Institute, Busan 619-705, Korea \\ ${ }^{2}$ Department of Marine Bio-materials and Aquaculture, and ${ }^{3}$ Department of Microbiology, Pukyong National University, \\ Busan 608-737, Korea
}

(Received on March 8, 2015; Revised on March 28, 2015; Accepted on April 7, 2015)

\begin{abstract}
Diatoms are a major component of the biological community, serving as the principal primary producers in the food web and sustaining oxygen levels in aquatic environments. Among marine planktonic diatoms, the cosmopolitan Skeletonema costatum is one of the most abundant and widespread species in the world's oceans. Here, we report the basic characteristics of a new diatom-infecting $S$. costatum virus (ScosV) isolated from Jaran Bay, Korea, in June 2008. ScosV is a polyhedral virus $(45-50 \mathrm{~nm}$ in diameter) that propagates in the cytoplasm of host cells and causes lysis of $S$. costatum cultures. The infectivity of $S \cos V$ was determined to be strain- rather than species-specific, similar to other algal viruses. The burst size and latent period were roughly estimated at $\mathbf{9 0 - 2 5 0 ~ i n f e c t i o u s ~ u n i t s / c e l l ~ a n d ~}$ $<48 \mathrm{~h}$, respectively.
\end{abstract}

Keywords : algal virus, diatom, Skeletonema costatum

Diatoms are an important component of the biological community, serving as the principal primary producers in the food web and sustaining oxygen levels in aquatic environments. Diatoms also function in global carbon fixation, especially during spring blooms in coastal, offshore, oceanic, and polar regions (Rines and Theriot, 2003; Sarthou et al., 2005). Among marine planktonic diatoms, the cosmopolitan Skeletonema costatum is one of the most abundant and widespread species, with 11 subspecies throughout the world oceans (Kooistra et al., 2008; Sarno et al., 2007, 2005). S. costatum is the most common diatom group along the Korean coast, occurring from April to August with peaks in abundance during the spring bloom.

*Corresponding author.

Phone) +82-51-629-5617, FAX) +82-51-629-5619

E-mail)choitj@pknu.ac.kr
Temperature, climate, salinity, nutrients and predators are important factors controlling the abundance and population dynamics of phytoplankton, including diatoms. In addition, viral infection poses a potential source of mortality, and several studies of algal-infecting viruses have appeared since the discovery of the first diatom virus, a singlestranded (ss) RNA virus that infects Rhizosolenia setigera (RsRNAV; Nagasaki et al., 2004).

Seawater contains many diverse organisms, including viruses and their hosts. One milliliter of seawater is estimated to contain $10^{5}$ to $10^{9}$ viral particles. Most of these viruses infect bacteria, cyanobacteria, archaea, and other eukaryotic organisms, but some infect macro- or microalgae. These algal viruses play an ecologically significant role in regulating the population dynamics of their phytoplankton hosts (Bratbak and Heldal, 1993; Suttle et al., 1990; Tarutani et al., 2000).

Over 50 viruses or virus-like particles (VLPs) infecting marine eukaryotic algae have been isolated and characterized over the past two decades (Nagasaki 2008; Nagasaki and Bratbak, 2010; Willson et al., 2009). To date, many algal host-virus systems have been established in laboratories and studied to various extents (Nagasaki, 2008; Van Etten et al., 1991; Van Etten and Meints, 1999). Among these species (excluding RsRNAV), at least nine diatom viruses have been isolated and characterized to date including Chaetoceros salsugineum nuclear inclusion virus (CsalDNAV, previously reported as CsNIV; Nagasaki et al., 2005), Chaetoceros nuclear inclusion virus (CspNIV; Bettarel et al., 2005) infecting Chaetoceros cf. gracilis, Chaetoceros debilis DNA virus (CdebDNAV; Tomaru et al., 2008), Chaetoceros tenuissimus RNA virus (CtenRNAV; Shirai et al., 2008), Chaetoceros socialis f. radians RNA virus (CsfrRNAV; Tomaru et al., 2009), Chaetoceros cf. wighamii nuclear inclusion virus (CwNIV; Eissler et al., 2009), Chaetoceros lorenzianus DNA virus (ClorDNAV; Tomaru et al., 2011); Chaetoceros sp. DNA 
virus (Csp05DNAV; Toyoda et al., 2012), and Chaetoceros setoensis DNA virus (CsetDNAV; Tomaru et al., 2013).

The present study reports the isolation and physiological characterization of a new diatom virus, ScosV, which infects $S$. costatum from Korean coastal water.

Seawater samples were collected from Jaran Bay, Korea, between May and October 2008. In the laboratory, samples were filtered through $0.8 \mu \mathrm{m}$ pore-size polycarbonate filters (Nuclepore, VA). The host organism, S. costatum (strain ME-SCM-1), was provided by the National Fisheries Research and Development Institute in Korea and was cultured in modified f/2 medium (Gillard, 1973) under a 12L:12D cycle of 80 to $90 \mu \mathrm{mol}$ photons $/ \mathrm{m}^{2} / \mathrm{s}$ with cool white fluorescent illumination at $20^{\circ} \mathrm{C}$. Logarithmic-phase cultures of $S$. costatum $(500 \mathrm{ml})$ were inoculated with 20 $\mathrm{ml}$ of the filtered sea water and incubated under the same conditions as above. Cultures and cells of $S$. costatum were lysed by the filtrate and became pale in color, presumably due to the loss or degradation of photosynthetic pigments. To confirm that virus particles were present, a lysate of a S. costatum culture was filtered through $0.2 \mu \mathrm{m}$ pore-size Dismic-25cs filters (Advantec, Charlotte, NC). Incubation with the viral lysate caused complete lysis of host cultures within 1 week, whereas controls remained healthy (Fig. 1A, B). Further cloning of the virus strain was performed following the method of Tarutani et al. (2001), and the isolated virus was named $S$. costatum infecting virus (ScosV).

The host range of $\mathrm{Scos} V$ was examined by adding $50 \mu \mathrm{l}$ of the original pathogen suspension to $1 \mathrm{ml}$ of exponentially growing cultures of the algal strains listed in Table 1. Each culture was incubated under the appropriate conditions and observed via optical microscopy. ScosV was not lytic to any of the microalgal species tested, other than $S$. costatum; moreover, it was not lytic to any other diatom strain tested (Table 1). The infectivity of ScosV was therefore considered to be not only species-specific, but also strain-specific, similar to several other algal viruses (Tomaru et al., 2004a, 2004b, 2008). The strain specificity of an algal virus is important for the maintenance of intraspecies diversity in algal populations in nature. The number of host strains tested in the present study was limited, but isolations of more virus isolates and host stains will elucidate the dynamic relationships between $S$. costatum and viruses infecting this host species.

The replication parameters of $\mathrm{S} \cos \mathrm{V}$ were determined using growth experiments. Cultures containing $500 \mathrm{ml}$ of exponentially growing host cells were inoculated with 20 $\mathrm{ml}$ of lysate containing $\mathrm{S} \cos \mathrm{V}$ at a viral titer of $2.67 \times 10^{7}$, estimated using the most probable number (MPN) method;

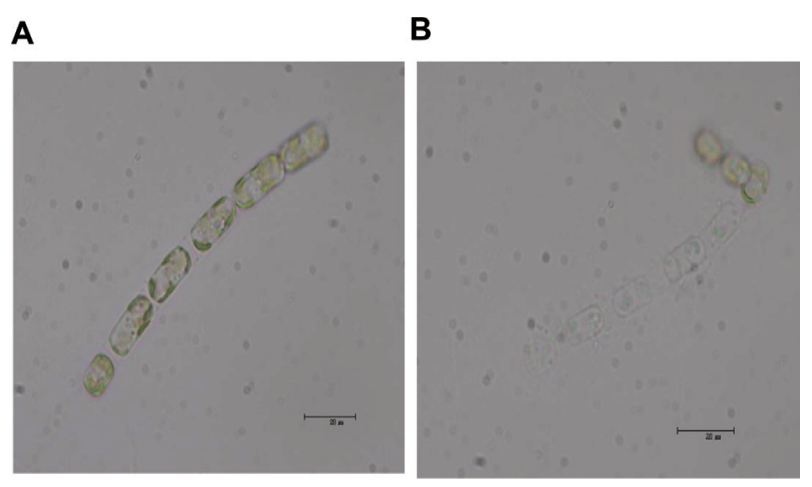

Fig. 1. Images of a healthy culture and a Skeletonema costatum virus ( $\mathrm{S} \cos \mathrm{V})$-inoculated culture. Light micrographs of a $S$. costatum culture at 0 days (A) and 4 days (B) post-inoculation with $\mathrm{ScosV}$.

the cell density and virus titer were then measured under light microscopy and using the extinction dilution method, respectively (Tarutani et al., 2001), every $12 \mathrm{~h}$ until reaching 80 hours post inoculation (hpi) (Fig. 2). An increase in viral titer was detected from 24 to $72 \mathrm{hpi}$; thus, the lytic cycle of $\mathrm{S} \cos \mathrm{V}$ was predicted to be $<48 \mathrm{~h}$. Furthermore, by comparing the decrease in host cell abundance to the increase in viral titer from 48 to $72 \mathrm{hpi}$, the burst size was estimated at 90-250 infectious units/cell. The latent period of ScosV was similar to those of other microalgal viruses (Nagasaki et al., 2003) and fell between those previously reported for diatom-infecting viruses such as CsNIV (Nagasaki et al., 2005) and CspNIV (Bettarel et al., 2005), which were 40-56 h and 24-48 h, respectively. However, the estimated burst size was markedly smaller than that of CsNIV, which has a burst size of 325 infectious units per host cell.

The morphology of ScosV was observed via transmission electron microscopy (TEM). S. costatum cultures were inoculated with $\mathrm{Scos} \mathrm{V}$, and 10-ml samples were collected at $0,12,24,36,48,60,72,84$, and 96 hpi and fixed with $1 \%$ glutaraldehyde in $\mathrm{f} / 2$ medium for $2 \mathrm{~h}$ at $4^{\circ} \mathrm{C}$. Cells were harvested by centrifugation at 3,000 rpm for $20 \mathrm{~min}$ and then post-fixed for an additional $1 \mathrm{~h}$ with $2 \%$ osmium tetroxide at $4^{\circ} \mathrm{C}$. Following two rinses with phosphate-buffered saline (PBS), the pellet was dehydrated in a graded ethanol series (20-100\%) and embedded in Poly/Bed ${ }^{\circledR} 812$ resin (Polyscience, Inc., Warrington, PA). Thin sections were stained with $4 \%$ uranyl acetate and 3\% lead citrate and observed under a TEM (JEOL JEM-1010; JEOL Ltd., MA) with an acceleration voltage of $60 \mathrm{kV}$. VLPs that were negatively stained with $4 \%(\mathrm{w} / \mathrm{v})$ uranyl acetate were also observed under TEM. Briefly, a drop of purified virus suspension was mounted on a grid for $30 \mathrm{~s}$, and excess 
Table 1. Infection specificity of Skeletonema costatum virus (ScosV) against 30 strains of marine phytoplankton

\begin{tabular}{|c|c|c|c|}
\hline Class & Genus \& Species & Strain & Lysis by $\mathrm{S} \cos \mathrm{V}$ \\
\hline \multirow[t]{9}{*}{ Bacillariophyceae } & Asterionella glacialis & NF-F-Asa-1 & $-^{\mathrm{a}}$ \\
\hline & Chaetoceros sp. & PK-CH-1 & - \\
\hline & Chaetoceros curvisetus & ME-CCS-1 & - \\
\hline & Chaetoceros curvisetus & NF-F-CCS-2 & - \\
\hline & Stephanopyxis palmeriana & NF-D-SPA-1 & - \\
\hline & Skeletonema costatum & KMMCC-292 & - \\
\hline & Skeletonema costatum & ME-SCM-1 & + \\
\hline & Skeletonema sp. & ME-SCM-2 & - \\
\hline & Skeletonema sp. & KMMCC-226 & - \\
\hline Chlorophyceae & Dunaliella sp. & PK-F-DUN-SP-1 & - \\
\hline \multirow[t]{3}{*}{ Cryptomonadaceae } & Rhodomonas sp. & PK-F-RHO-SP-1 & - \\
\hline & Rhodomonas sp. & PK-F-RHO-SP-2 & - \\
\hline & Rhodomonas sp. & PK-F-RHO-SP-3 & - \\
\hline \multirow[t]{12}{*}{ Dinophyceae } & Akashiwo sanguinea & NF-F-AKA-1 & - \\
\hline & Alexandrium sp. & NF-F-ALE-SP-1 & - \\
\hline & Alexandrium sp. & NF-F-ALE-SP-2 & - \\
\hline & Alexandrium catenella & NF-F-ACA-1 & - \\
\hline & Amphidinium carterae & PK-F-ACA-1 & - \\
\hline & Cochlodinium polykrikoides & NF-F-CPO-3 & - \\
\hline & Gymnodinium impudicum & NF-F-GIM-1 & - \\
\hline & Gymnodinium sp. (Heterocapsa pygmaea) & NF-F-GYM-SP-1 & - \\
\hline & Gymnodinium sp. & NF-F-GYM-SP-2 & - \\
\hline & Prorocentrum minimum & NF-F-PMI-1d & - \\
\hline & Prorocentrum minimum & PK-F-PMI-2 & - \\
\hline & Prorocentrum micans & NF-F-PMC-1 & - \\
\hline Euglenophyceae & Eutreptia sp. & NF-F-EUT-SP-1 & - \\
\hline Prymnesiophyceae & Prymnessium parvum & PK-F-Pry-SP-1 & - \\
\hline \multirow[t]{4}{*}{ Raphidophyceae } & Heterosigma akashiwo & NF-F-HAK-1 & - \\
\hline & Heterosigma akashiwo & PK-F-HAK-1 & - \\
\hline & Heterosigma akashiwo & PK-F-HAK-2 & - \\
\hline & Chattonella antiqua & NF-F-CAN-1 & - \\
\hline
\end{tabular}

${ }^{\mathrm{a}+:}$ lysed; -: not lysed

water removed using filter paper. After the grid had dried, negatively stained VLPs were observed via TEM under the same conditions. Particle diameters were estimated on negatively stained images.

Intracellular VLPS were observed $72 \mathrm{~h}$ after inoculation with ScosV. These VLPS were $\sim 38-46 \mathrm{~nm}$ in diameter and appeared as electron-opaque particles in the cytoplasm (Fig. 3B, C and D). No typical crystalline array formation was observed. VLPs were not found in healthy control cells (Fig. 3A). Virus particles appeared hexagonal in outline upon negative staining, were $40 \pm 10 \mathrm{~nm}$ in diameter had no outer membrane or tail-like structure (Fig. 3E), and were similar to VLPs observed in the cytoplasm (Fig. 3D). The size, icosahedral morphology, and cytoplasmic site of virus assembly are properties shared by algal virus VLPs
(Van Etten et al., 1991), including C. salsugineum VLPs (38 nm; Nagasaki et al., 2005) and C. lorenzianus VLPs ( $34 \pm 2 \mathrm{~nm}$; Tomaru et al., 2011). Because 1) the algicidal pathogen was transferable to a fresh algal culture, 2) VLPs were observed in the culture lysate, and, 3) VLPs were not observed in healthy cultures, we concluded that the VLPs observed in cytoplasm were pathogenic to $S$. costatum.

The effect of storage temperature on ScosV infectivity was examined following the methods of Tomaru et al., (2005). An exponentially growing culture of $S$. costatum was inoculated with the virus and incubated for 4 days. The resultant lysate was sequentially passed through 0.8 $\mu \mathrm{m}$ and $0.22 \mu \mathrm{m}$ filters to remove cell debris. The titer of the fresh lysate, estimated using the extinction dilution method, was $2.7 \times 10^{7}$ infectious units $/ \mathrm{ml}$. Aliquots of the 

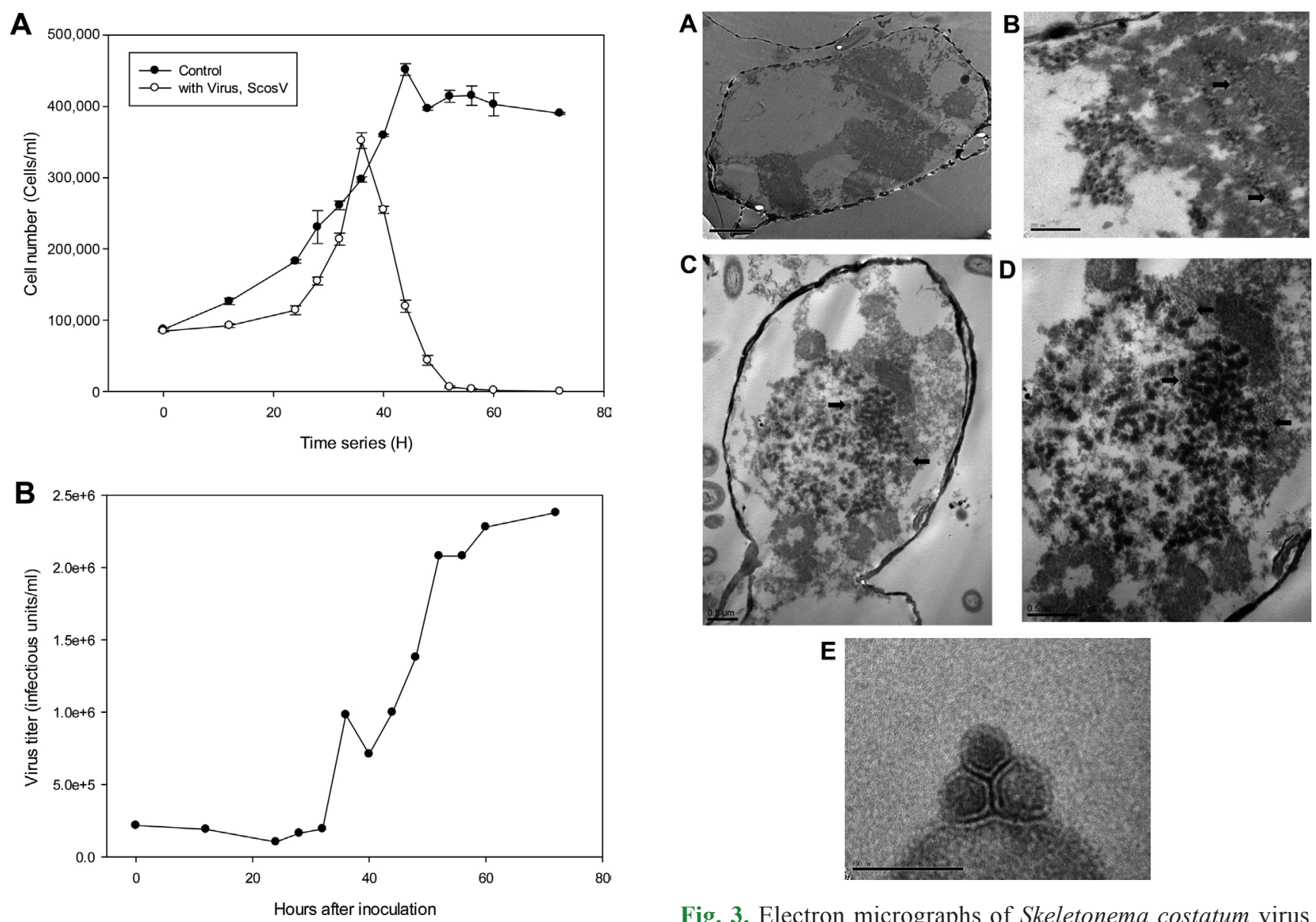

Fig. 2. Multiplication of Skeletonema costatum virus (ScosV) in inoculated hosts. (A) Changes in host cell numbers with $(\bullet)$ or without (O) inoculation of ScosV. (B) Virus titer in the inoculated culture was calculated using the extinction dilution method.

lysate were stored at $20,15,4$, and $-196^{\circ} \mathrm{C}$ (liquid nitrogen) under light or dark conditions with or without $10 \%$ or $20 \%$ dimethyl sulfoxide (DMSO) as a cryoprotectant, and were then re-titrated using the extinction dilution method. After 2 weeks of storage at 4,15 , and $20^{\circ} \mathrm{C}$ in the dark, the estimated titers were $5.1 \times 10^{5}, 7.74 \times 10^{4}$, and $2.3 \times 10^{3}$ infectious units $/ \mathrm{ml}$, respectively; however, titers fell below the detection limit $\left(<3.0 \times 10^{1}\right.$ infectious units $\left./ \mathrm{ml}\right)$ after 4 months of storage at each temperature. Decreases in infectious titers have been reported for other microalgal viruses, such as CtenRNAV and CsfrRNAV, which exhibit considerable decay even under cold and dark conditions (Shirai et al., 2008; Tomaru et al., 2009). Based on these results, a significant loss of infectivity may occur in natural environments. Cryopreservation conditions for ScosV were optimized using a method similar to those of Nagasaki and Yamaguchi (1999) and Tomaru et al. (2005); the highest titers $\left(2.1 \times 10^{5}\right.$ infectious units $\left./ \mathrm{ml}\right)$ after 1 month

Fig. 3. Electron micrographs of Skeletonema costatum virus ( $\mathrm{S} \cos \mathrm{V})$. (A) Healthy cells of Skeletonema costatum MESCM-1. (B-D) Cells infected by the pathogen ScosV. (B) 36 $\mathrm{h}$ post inoculation. (C) $60 \mathrm{~h}$ post inoculation; numerous, small dense masses appear to be fragmenting. (D) Higher magnification image of the virus-like particles in the host cytoplasm. (E) Negatively stained virus-like particles from lysate.

of storage were recorded when the viral suspension was preserved in liquid nitrogen $\left(-196^{\circ} \mathrm{C}\right)$ with $10 \%$ DMSO as a cryoprotectant (initial concentration $=100 \%$; Merck, NY). The temperature stability of the diatom virus group is high (Tomaru et al., 2008, 2011; Toyoda et al., 2012).

Viruses are thought to influence community composition by infecting principally competitively superior host species that are abundant and fast-growing (Sandaa, 2008; Wommack and Colwell, 2000). Although we do not have sufficient data to determine the roles played by viruses in marine environments, or in host population dynamics, the interaction between Phaeocystis pouchetii and the lytic virus PpV01 in laboratory microcosms (Bratbak and Heldal, 2000) and the ecological relationship between the bloom-forming dinoflagellate Heterocapsa circularisquama and its infectious virus, HcRNAV, afford 
plausible explanations of the roles played by viruses in the dynamics of host algae (Nagasaki et al., 2003; Tomaru and Nagasaki, 2004).

\section{Acknowledgments}

This work was supported by National Research Foundation of Korea Grant funded by the Korean Government (NRF2012R1A1A4A01004076) and by grants from the National Fisheries Research \& Development Institute (NFRDI) of Korea (15-OE-29, Fundamental study on the practical use of eco-friendly removal materials of $\mathrm{HABs}$ ).

\section{References}

Bettarel, Y., Kan, J., Wang, K., Williamson, K. E., Cooney, S., Ribblett, S., Chen, F., Wommack, K. E. and Coats, D. W. 2005. Isolation and preliminary characterization of a small nuclear inclusion virus infecting the diatom Chaetoceros $\mathrm{cf}$. gracilis. Aquat. Microb. Ecol. 40:103-114.

Bratbak, G. and Heldal, K. 1993. Total counts of viruses in aquatic environments. In: Current Methods in Aquatic Microbial Ecology, eds. by P. F. Kemps, B. F. Sherr, E. B. Sherr, and J. J. Cole, pp. 135-148. Lewis, London, UK.

Bratbak, G. and Heldal, K. 2000. Significance of algal viruses and ecology of Phaeocystis host-virus interactions. In: Microbial Biosystems, eds. by C. Bell, M. Brylinsky, and P. JohnsonGreen, pp. 571-575. Atlantic Canada Society for Microbial Ecology, Halifax, Canada.

Eissler, Y., Wang, K., Chen, F., Wommack, E. and Coats, W. 2009. Ultrastructural characterization of the lytic cycle of an intranuclear virus infecting the diatom Chaetoceros cf. wighamii (bacillariophyceae) from Chesapeake Bay, USA. $J$. Phycol. 45:787-797.

Guillard, R. R. L. 1973. Culture of phytoplankton for feeding marine invertebrates. In: Culture of Marine Invertebrate Animals, eds. by W. L. Smith and M. M. Charley, pp. 29-60. Plenum Press, New York, USA.

Kooistra, W. H. C. F., Sarno, D., Balzano, S., Gu, H., Anderson, R. A. and Zingone, A. 2008. Global diversity and biogeography of Skeletonema species (Bacillariophyta). Protist 159:177193.

Nagasaki, K. 2008. Dinoflagellates, diatoms and their viruses. $J$. Microbiol. 46:235-243.

Nagasaki, K. and Bratbak, G. 2010. Isolation of viruses infecting photosynthetic and non-photosynthetic protists. Manual Aquat. Viral Ecol. 10:92-101.

Nagasaki, K., Tomaru, Y., Takao, Y., Nishida K., Shirai Y., Suzuki, H. and Nagumo, T. 2005. Previously unknown virus infects marine diatom. Appl. Environ. Microb. 71:3528-3535.

Nagasaki, K., Tomaru, Y., Katanozaka, N., Shirai, Y., Nishida, K., Itakura, S. and Yamaguchi, M. 2004. Isolation and characterization of a novel single-stranded RNA virus infecting the bloom-forming diatom Rhizosolenia setigera. Appl. Environ. Micro. 70:704-711.

Nagasaki, K., Tomaru, Y., Nakanishi, K., Hata, N., Katanozaka, N., Yamanaka, S., Tanabe, H. and Yamaguchi, M. 2003. Growth characteristics and intra-species host specificity of a large virus infecting the dinoflagellate Heterocapsa circularisquama. Appl. Environ. Microb. 69:2580-2586.

Nagasaki, K. and Yamaguchi, M. 1999. Cryopreservation of a virus $(\mathrm{HaV})$ infecting a harmful bloom causing microalga, Heterosigma akashiwo (Raphidophyceae). Fish. Sci. 65:319320.

Rines, J. E. B. and Theriot, E. C. 2003. Systematics of Chaetocerotaceae (Bacillariophyceae): I. A phylogenetic analysis of the family. Phycol. Res. 51:83-98.

Sandaa, R. A. 2008. Burden or benefit? Virus - host interactions in the marine environment. Res. Microbiol. 159:374-381.

Sarno, D., Kooistra, W. H. C. F., Medlin, L. K., Percopo, I. and Zingone, A. 2005. Diversity in the genus Skeletonema (Bacillariophyceae): II. An assessment of the taxonomy of S. costatum-like species with the description of four new species. J. Phycol. 41:151-176.

Sarno, D., Kooistra, W. H. C. F., Balzano, S., Hargraves, P. E. and Zongone, A. 2007. Diversity in the genus Skeletonema (Bacillriophyceae): III. Phylogenetic position and morphological variability of Skeletonema costatum and Skeletonema grevillei, with the description of Skeletonema ardens sp. nov. J. Phycol. 43:156-170.

Sarthou, G., Timmermans, K. R., Blain, S. and Treguer, P. 2005. Growth physiology and fate of diatoms in the ocean: A review. J. Sea Res. 53:25-42.

Shirai, Y., Tomaru, Y., Takao, Y., Suzuki, H., Nagumo, T. and Nagasaki, K. 2008. Isolation and characterization of a singlestranded RNA virus infecting the marine planktonic diatom Chaeroceros tenuissimus Meunier. Appl. Environ. Microb. 74: 4022-4027.

Suttle, C. A., Chan, A. M. and Cottell, M. T. 1990. Infection of phytoplankton by viruses and reduction of primary productivity. Nature 49:781-788.

Tarutani, K., Nagasaki, K., Itakura, S. and Yamaguchi, M. 2001. Isolation of a virus infecting the novel shellfish-killing dinoflagellate Heterocapsa circularisquama. Aquat. Microb. Ecol. 23:103-111.

Tarutani, K., Nagasaki, K. and Yamaguchi, M. 2000. Viral impacts on total abundance and clonal composition of the harmful bloom-forming phytoplankton Heterosigma ahaskiwo. Appl. Environ. Microb. 66:4916-4920.

Tomaru, Y., Katanozaka, N., Nishida, K., Shirai, Y., Tarutani, K., Yamaguchi, M. and Nagasaki, K. 2004a. Isolation and characterization of two distinct types of HcRNAV, a singlestranded RNA virus infecting the bivalve-killing microalga Heterocapsa circularisquama. Aquat. Microb. Ecol. 34:207218.

Tomaru, Y. and Nagasaki, K. 2004. Widespread occurrence of viruses lytic to the bivalve-killing dinoflagellate along the 
western coast of Japan. Plankton Biol. Ecol. 51:1-6.

Tomaru, Y., Shirai, Y., Suzuki, H., Nagasaki, T. and Nagumo, T. 2008. Isolation and characterization of a new single-stranded DNA virus infecting the cosmopolitan marine diatom Chaetoceros debilis. Aquat. Microb. Ecol. 50:103-112.

Tomaru, Y., Takao, Y., Suzuki, H., Nagumo, T., Koike, K. and Nagasaki, K. 2011. Isolation and characterization of a singlestranded DNA virus infecting Chaetoceros lorenzianus Grunow. Appl. Environ. Microb. 77:5285-5293.

Tomaru, Y., Takao, Y., Suzuki, H., Nagumo, T. and Nagasaki, K. 2009. Isolation and characterization of a single-stranded RNA virus infecting the bloom-forming diatom Chaetoceros socialis. Appl. Environ. Microb. 75:2375-2381.

Tomaru, Y., Tanabe, H., Yamanaka, S. and Nagasaki, K. 2005. Effects of temperature and light on stability of microalgal viruses, $\mathrm{HaV}, \mathrm{HcV}$ and HcRNAV. Plankton Biol. Ecol. 52:1-6.

Tomaru, Y., Tarutani, K., Yamaguchi, M. and Nagasaki, K. 2004b. Quantitative and qualitative impacts of viral infection on a Heterosigma akashiwo (Raphidophyceae) bloom in Hiroshima Bay, Japan. Aquat. Microb. Ecol. 34:227-238.
Tomaru, Y., Toyoda, K., Suzuki, H., Nagumo, T., Kimura, K. and Takao, Y. 2013. New single-stranded DNA virus with a unique genomic structure that infects marine diatom Chaetoceros setoensis. Sci. Rep. 3:3337.

Toyoda, K., Kimura, K., Hata, N., Nakayama, N., Nagasaki, K. and Tomaru, Y. 2012. Isolation and characterization of a single-stranded DNA virus infecting the marine planktonic diatom Chaetoceros sp. (strain TG07-C28). Plankton Benthos Res. 7:20-28.

Van Etten, J. L., Lane, L. C. and Meints, R. H. 1991. Viruses and virus-like particles of eukaryotic algae. Microbiol. Rev. 55: 586-620.

Van Etten, J. L. and Meints, R. H. 1999. Giant viruses infecting algae. Annu. Rev. Microbiol. 53:447-494.

Wilson, W. H., Van Etten, J. L. and Allen, M. J. 2009. The Phycodnaviridae: the story of how tiny giants rule the world. Curr. Top. Microbiol. Immunol. 328:1-42.

Wommack, K. R. and Colwell, R. R. 2000. Virioplankton: Viruses in aquatic ecosystems. Microbiol. Mol. Biol. Rev. 64:69114. 